\title{
Design of Children's Motor Training Tools Using Sensor-Based Agility Components in Physical Education Learning
}

\author{
https://doi.org/10.3991/ijim.v16i05.29731 \\ Anton Komaini ${ }^{1(\bowtie)}$, Hermanzoni ${ }^{1}$, Sri Gusti Handayani ${ }^{1}$, \\ Muhamad Sazeli Rifki ${ }^{1}$, Yanuar Kiram ${ }^{1}$, Novadri Ayubi ${ }^{2}$ \\ ${ }^{1}$ Faculty of Sports Science, Universitas Negeri Padang, Padang, Indonesia \\ ${ }^{2}$ Postgraduate, Universitas Negeri Surabaya, Surabaya, Indonesia \\ antonkomaini@fik.unp.ac.id
}

\begin{abstract}
The This study aims to design a motor skill training tool for children using sensor-based agility components in pgysical education learning. This study uses a research and development design. the materials used are Arduino, Connector, LED, Sensor tool, Power button, and Tool cover. After the product design is made, Collecting research data by conducting direct interviews with experts. it will then be validated by a competent expert. In this study, we asked for validation from three experts, namely: (1) evaluation and exercise evaluation (2) instrumentation physicist (3) motor skills expert. Collecting research data by conducting direct interviews with experts. Based on the expert validation test, the design of skill training tools using sensor-based agility components gets effective results, so that they can be used to carry out motor skills exercises. The importance of motor skills as the basis for every child's active life, with the help of tools to help children to encourage themselves to practice, Design of motor skills training tools with sensor-based agility components has the potential and effectiveness to train children's motor skills.
\end{abstract}

Keywords—motor skills, exercise, agility, sensor technology

\section{Introduction}

Physical activity is very decisive and becomes an important thing for children's lives because it has a good impact on children's health and development [1,2]. Physical, cognitive, and social development are closely related to children's motor skills [3-6]. Good motor skills are considered very important and also form the basis for an active lifestyle for every child $[7,8]$. On the other hand, motor skills depend on new connections in the central nervous system and the experience of interacting with the environment $[9,10]$. In addition, motor skills are one of the determining factors for children's success in achieving sports achievements and motivation $[11,12]$. Poor motor skills will result in a child limiting himself to participate in physical activities with the surrounding environment, so that it will also have an impact on social understanding [9]. 
It is reported that 41 million children worldwide are obese due to poor motor skills so that children are lazy to do physical activities or sports [13]. The World Health Organization (WHO) recognizes poor motor skills in children, one of which is caused by a developmental coordination disorder [14]. In general, this occurs due to lack of motor skills training at an early age $[15,16]$.

One alternative solution to overcome poor motor skills is to do physical exercise such as agility training. Agility training has the potential to improve the quality of motor skills by controlling and maintaining body position when changing directions [17]. In addition, agility training also leads to balance skills, speed, and physical coordination skills [18]. Today various sensor technologies are combined with sports devices [19]. It is also driven by technological advances and lower costs. Sensor technology is widely used to measure heart rate and measure temperature that is embedded in personal devices such as smartphones and digital watches [19-23]. However, until now there has never been a combination of sensor technology tools and agility components to improve children's motor skills in the physical education learning process.

Our research aims to design a motor skill training tool for children using sensor-based agility components in physical education learning.

\section{$2 \quad$ Research methods}

This research is a type of research with research and development design. After the product design is made, this research requires validation by competent experts. Validation is carried out by competent experts aiming to find out the weaknesses and strengths of the product. In this study, the researcher asked for validation from three experts, namely: (1) sports evaluation and measurement expert (2) instrumentation physicis expert (3) motor skills expert. Collecting data in this study by conducting direct interviews with experts.

\section{Materials}
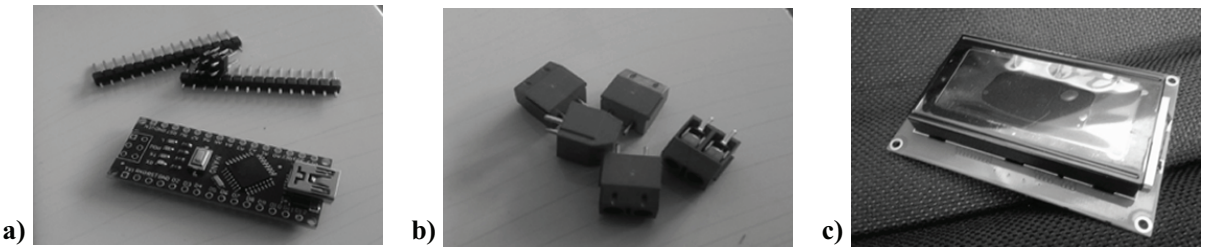

Fig. 1. a) Arduino, b) Connector, c) LED [24] 

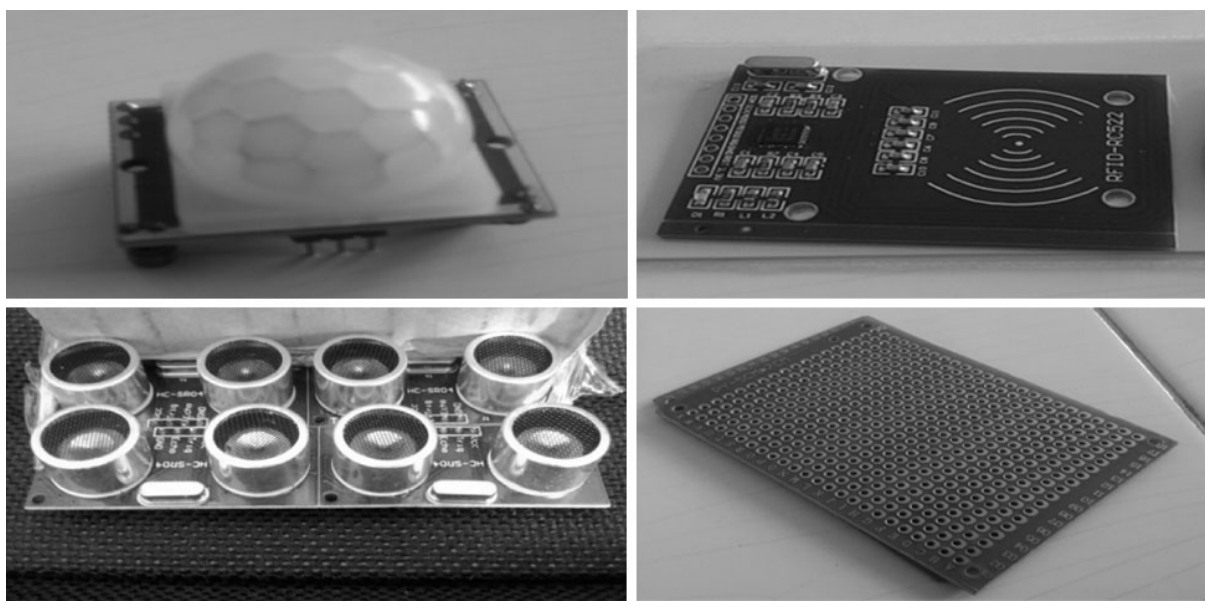

Fig. 2. Sensor tool [25]
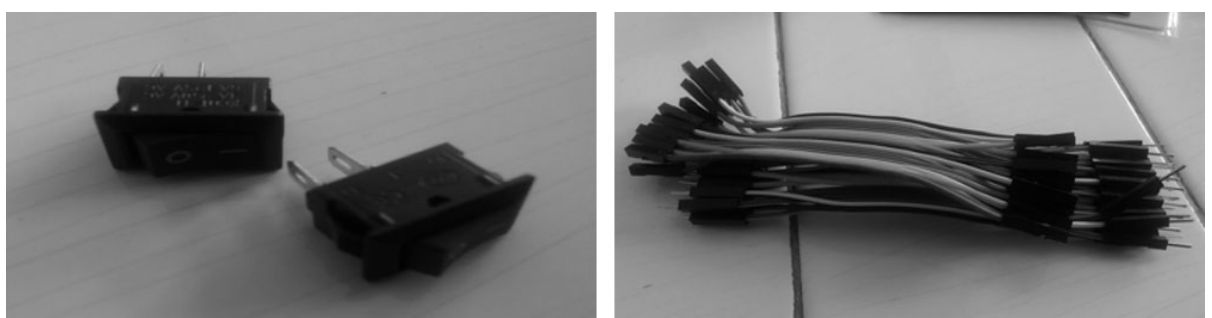

Fig. 3. Power button $[25]$

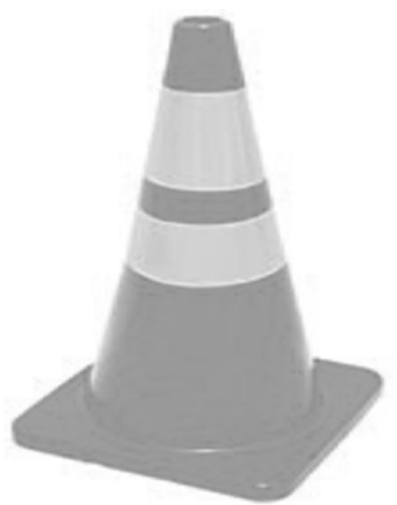

Fig. 4. Tool cover [26] 
Overview of the use of the tool:

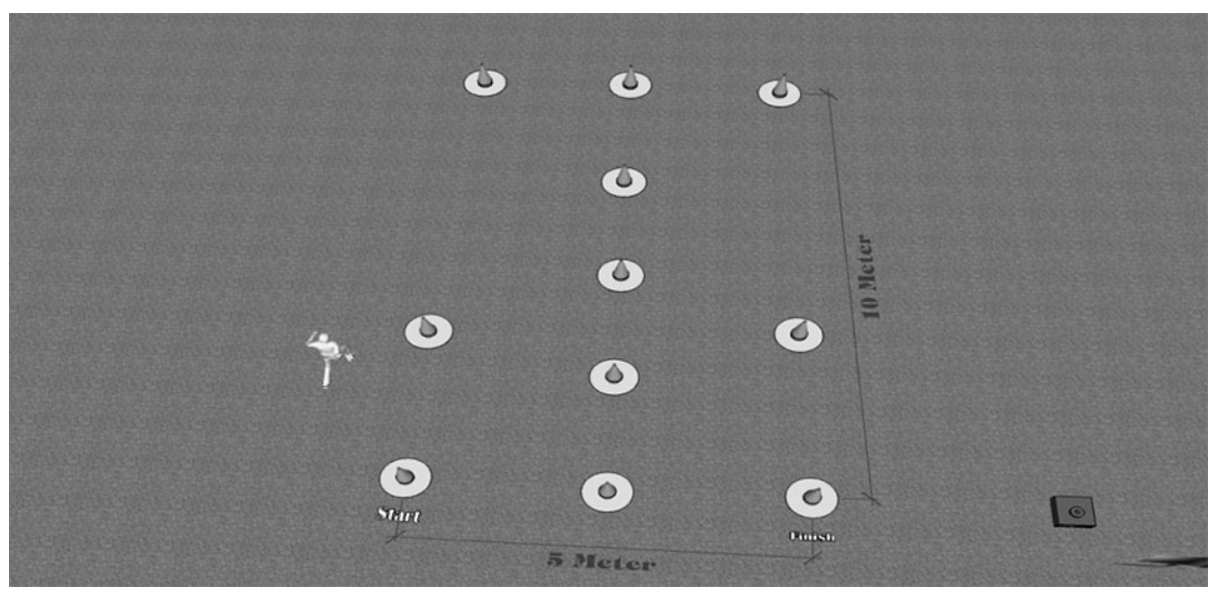

Fig. 5. Use of tools [26]

\section{Results}

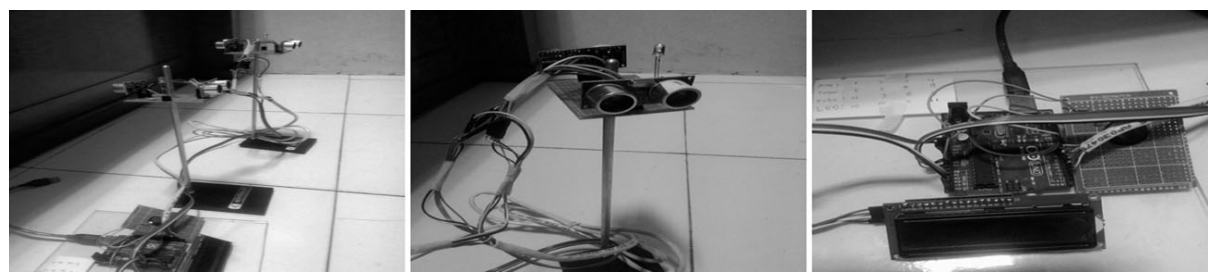

Fig. 6. Design results of motor skills training tools using sensor-based agility components 


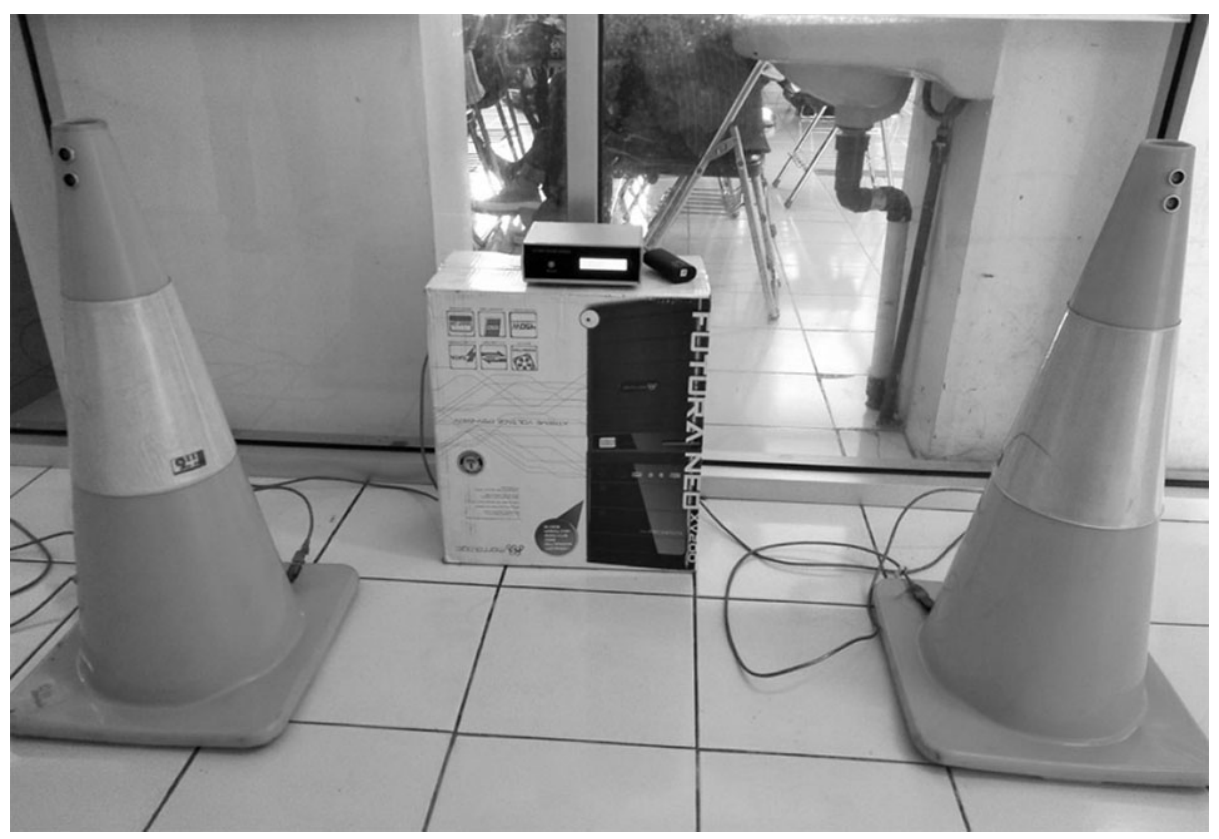

Fig. 7. The final product of motor skills training tools

\section{Expert validation test}

Table 1. The results of the interview validation test for the accuracy of the tool

\begin{tabular}{|l|l|}
\hline \multicolumn{1}{|c|}{ Expert } & \multicolumn{1}{c|}{ Interview Result } \\
\cline { 2 - 3 } measurement & $\begin{array}{l}\text { Accuracy } \\
\text { Basically, the development of an exercise tool to improve the motor skills } \\
\text { of the agility component refers to the definition of the variables observed } \\
\text { first. If according to the definition, then the tool can be used in training } \\
\text { the agility. Overall, the product developed represents the definition of the } \\
\text { variable being trained, namely agility. So that this tool can be used as an } \\
\text { exercise tool to improve the motor skills of the agility component. }\end{array}$ \\
\hline Instrumentation physicis & $\begin{array}{l}\text { The concept is in accordance with the concept of agility work from } \\
\text { the point of view of physics. It's just that it needs to be adjusted to the } \\
\text { needs of the sports branch. In principle, the instrument developed was } \\
\text { appropriate to measure agility. It is necessary to pay attention to the } \\
\text { components used so that they are closer to the purpose of developing } \\
\text { the tool, such as sensors and other components. }\end{array}$ \\
\hline Motor skills & $\begin{array}{l}\text { In terms of motor skills, this tool can provide a higher movement } \\
\text { experience specifically for the agility component. }\end{array}$ \\
\hline
\end{tabular}


Table 2. Interview validation test results for the implementation of the tool

\begin{tabular}{|l|l|}
\hline \multicolumn{1}{|c|}{ Expert } & \multicolumn{1}{c|}{ Interview Result } \\
\cline { 2 - 2 } & \multicolumn{1}{c|}{ Implementation } \\
\hline $\begin{array}{l}\text { Sports evaluation and } \\
\text { measurement }\end{array}$ & $\begin{array}{l}\text { To determine the measurement results can be done in several ways, one of } \\
\text { which is through several repetitions. So based on the observations made, } \\
\text { the implementation of data collection was developed in accordance with } \\
\text { the measurement principle. }\end{array}$ \\
\hline Instrumentation physicis & In accordance with the principle of carrying out measurements. \\
\hline Motor skills & $\begin{array}{l}\text { If viewed from the side of the implementation principle, it can be said that } \\
\text { the designed product work procedure is correct. However, it needs to be } \\
\text { further adjusted to the sports needs that each child is interested in. }\end{array}$ \\
\hline
\end{tabular}

Table 3. Interview validation test results for tool improvement

\begin{tabular}{|l|l|}
\hline \multicolumn{1}{|c|}{ Expert } & \multicolumn{1}{c|}{ Interview Result } \\
\cline { 2 - 3 } $\begin{array}{l}\text { Sports evaluation and } \\
\text { measurement }\end{array}$ & $\begin{array}{l}\text { Improvement } \\
\text { The tool should be more mobile and easy to operate. So it needs } \\
\text { improvement on several sides of the tool. Like the connecting cable for } \\
\text { each sensor. }\end{array}$ \\
\hline Instrumentation physicis & $\begin{array}{l}\text { In terms of software and hardware as well as the work program of the tool, } \\
\text { it is necessary to improve and test the requirements for developing agility } \\
\text { instruments. Among other things, test the accuracy of the tool and test } \\
\text { the consistency of the tool. Furthermore, in order to avoid system errors } \\
\text { caused by damage to internal components, it is necessary to redesign } \\
\text { the components used. One of them is the manufacture of tools must be } \\
\text { packaged properly, so that it is more sturdy when moved around (mobile). }\end{array}$ \\
\hline Motor skills & $\begin{array}{l}\text { Variations of training forms need to be developed, with the meaning that } \\
\text { the tool must be portable to adapt to the desired form of agility training. }\end{array}$ \\
\hline
\end{tabular}

\section{Discussion}

Training children's motor skills can be done by doing exercises such as agility exercises. Our research explains that the validity test was carried out with Sports evaluation and measurement experts, this tool can be used in training agility, the overall tool that has been designed includes all components related to agility. On the other hand, the implementation of data collection was developed in accordance with the measurement principle. Then the improvement in the design of this tool is more on several sides of the tool, such as the connecting cable for each sensor to make it easier to operate. Instrumentation physicis expert explained that from the point of view of physics this tool was in accordance with the concept of physics, the implementation was in accordance with the implementation of measurements and to avoid system errors caused by damage to internal components, it was necessary to redesign the components used. One of them is that the tool manufacturer must be packaged properly, so that it is more sturdy when being moved. Furthermore, the motor skills expert explained that this tool can provide high movement experience in the agility component, so that with this tool children can do exercises to improve their motor skills. In terms of the implementation 
of the design of this tool, the working procedures of this tool have been designed properly. On the other hand, improvements are needed in the form of variations in the forms of movement that are further developed so that when doing exercises this tool can adjust the desired form of exercise.

Coupled with research (Dapp, Gashaj and Roebers, 2021) [1] Regular physical exercise is effective in training the motor skills of long-term children. On research (Paul, Gabbett and Nassis, 2016) [27] Reporting Training a child's motor skills can be done by doing exercises such as agility training. Physical education taught by a professional teacher is very important to stimulate motor coordination so that it has a good impact on children's motor development [28]. The research design that we have designed also has the potential to provide assistance to teachers in implementing motor skills training using more effective and efficient tools.

Based on the development data carried out above. so we believe and believe this is the progress of a tool product that is designed to be more effective than the manual training model. Therefore. This tool is suitable to be used to improve the motor skills of the agility component.

\section{Conclusion}

The importance of motor skills as the basis for every child's active life, with the help of tools to help children to encourage themselves to practice, Design of motor skills training tools with sensor-based agility components has the potential and effectiveness to train children's motor skills in psysical education learning.

\section{Acknowledgment}

We would like to thank all the teams involved in this research, especially the experts so that we can complete the design of children's motor training tools using sensor-based agility components properly. And it cannot be separated from the role of lecturers, research subjects for their excellent cooperation so that research can be carried out smoothly.

\section{$7 \quad$ References}

[1] Dapp, L. C., Gashaj, V. \& Roebers, C. M. Physical activity and motor skills in children: A differentiated approach. Psychol. Sport Exerc. (2021) https://doi.org/10.1016/ j.psychsport.2021.101916

[2] Chen, W., Hammond-Bennett, A., Hypnar, A. \& Mason, S. Health-related physical fitness and physical activity in elementary school students. BMC Public Health. (2018) https://doi. org/10.1186/s12889-018-5107-4

[3] Hestbaek, L. et al. Influence of motor skills training on children's development evaluated in the Motor skills in PreSchool (MiPS) study-DK: Study protocol for a randomized controlled trial, nested in a cohort study. Trials (2017) https://doi.org/10.1186/s13063-017-2143-9 
[4] Chang, Y. T. Physical activity and cognitive function in mild cognitive impairment. ASN Neuro (2020) https://doi.org/10.1177/1759091419901182

[5] Ayubi, N. \& Komaini, A. The Impact of the COVID-19 Pandemic on Children's Motor Skills (Literature Review). Int. J. Res. Publ. 90, 66-70 (2021) https://doi.org/10.47119/ IJRP1009011220212517

[6] Komaini, A. \& Mardela, R. Differences of fundamental motor skills stunting and non stunting preschool children in kindergarten in North Padang. in IOP Conference Series: Materials Science and Engineering (2018) https://doi.org/10.1088/1757-899X/335/1/012131

[7] Wainwright, N. et al. Developing children's motor skills in the Foundation Phase in Wales to support physical literacy. Educ. 3-13 (2020) https://doi.org/10.1080/03004279.2019.163 $\underline{3374}$

[8] Komaini, A. et al. Motor learning measuring tools: a design and implementation using sensor technology for preschool education. Int. J. Interact. Mob. Technol. (2021) https://doi. org/10.3991/ijim.v15i17.25321

[9] Leonard, H. C. The impact of poor motor skills on perceptual, social and cognitive development: The case of developmental coordination disorder. Frontiers in Psychology (2016) https://doi.org/10.3389/fpsyg.2016.00311

[10] Gao, Z., Chen, S., Sun, H., Wen, X. \& Xiang, P. Physical Activity in Children's Health and Cognition. BioMed Research International (2018) https://doi.org/10.3390/ijerph15040800

[11] Wood, A. P., Imai, S., McMillan, A. G., Swift, D. \& DuBose, K. D. Physical activity types and motor skills in 3-5-year old children: National Youth Fitness Survey. J. Sci. Med. Sport (2020) https://doi.org/10.1016/j.jsams.2019.11.005

[12] Figueroa, R. \& An, R. Motor skill competence and physical activity in preschoolers: A review. Matern. Child Health J. (2017) https://doi.org/10.1007/s10995-016-2102-1

[13] Zeng, N. et al. Effects of physical activity on motor skills and cognitive development in early childhood: A systematic review. BioMed Research International (2017) https://doi. org $/ 10.1155 / 2017 / 2760716$

[14] dos Santos, L. R. V. \& de Castro Ferracioli, M. Prevalence of children identified with motor difficulties. Brazilian J. Occup. Ther. (2020) https://doi.org/10.4322/2526-8910.ctoAO1847

[15] Geertsen, S. S. et al. Motor skills and exercise capacity are associated with objective measures of cognitive functions and academic performance in preadolescent children. PLoS One (2016) https://doi.org/10.1371/journal.pone.0161960

[16] Forte, R., Ditroilo, M., Boreham, C. A. \& DE Vito, G. Strength training and gross-motor skill exercise as interventions to improve postural control, dynamic functional balance and strength in older individuals. J. Sports Med. Phys. Fitness (2021) https://doi.org/10.23736/ S0022-4707.21.11947-4

[17] João, P. V. et al. Physical activity with agility motor development for children ages 6-10. Sci. Sports (2014) https://doi.org/10.1016/j.scispo.2014.08.095

[18] Eler, N. \& Eler, S. The effect of agility exercises on the COD speed and speed in terms of the frequency of the training. Univers. J. Educ. Res. (2018) https://doi.org/10.13189/ ujer.2018.060908

[19] Li, R. T. et al. Wearable performance devices in sports medicine. Sports Health (2016) https://doi.org/10.1177/1941738115616917

[20] Kwon, S. Bin et al. Estimating maximal oxygen uptake from daily activity data measured by a watch-type fitness tracker: Cross-sectional study. JMIR mHealth uHealth (2019) https:// doi.org/10.2196/13327

[21] McKenzie, J. E. \& Osgood, D. W. Validation of a new telemetric core temperature monitor. in Journal of Thermal Biology (2004) https://doi.org/10.1016/j.jtherbio.2004.08.020 
[22] Terbizan, D. J., Dolezal, B. A. \& Albano, C. Validity of seven commercially available heart rate monitors. Meas. Phys. Educ. Exerc. Sci. (2002) https://doi.org/10.1207/ S15327841MPEE0604_3

[23] Bandodkar, A. J. \& Wang, J. Non-invasive wearable electrochemical sensors: A review Trends in Biotechnology (2014). https://doi.org/10.1016/j.tibtech.2014.04.00

[24] D'Ausilio, A. Arduino: A low-cost multipurpose lab equipment. Behav. Res. Methods (2012). https://doi.org/10.3758/s13428-011-0163-Z

[25] Rackus, D. G., Shamsi, M. H. \& Wheeler, A. R. Electrochemistry, biosensors and microfluidics: a convergence of fields. Chem. soc. Rev. (2015). https://doi.org/10.1039/C4CS00369A

[26] Salimi, Z. \& Ferguson-Pell, M. W. Investigating the test-retest reliability of Illinois Agility Test for wheelchair users. PLoS One (2020). https://doi.org/10.1371/journal.pone.0241412

[27] Paul, D. J., Gabbett, T. J. \& Nassis, G. P. Agility in team sports: Testing, training and factors affecting performance. Sports Medicine (2016). https://doi.org/10.1007/s40279-015-0428-2

[28] Gallahue, D. L., Ozmun, J. C. \& Goodway, J. C. Compreendendo o desenvolvimento motor: bebês, crianças, adolescentes e adultos. AMGH Editora Ltda (2013)

\section{Authors}

Anton Komaini, is a Doctor in Motor Learning. He is a Lecturer in the Department of Sports Science, Faculty of Sports Science, Universitas Negeri Padang, Indonesia. His research areas include Motor Learning, and Sports Education. Email: antonkomaini@, fik.unp.ac.id

Hermanzoni, is a Senior Lecturer in the Department of Sports Coaching, Faculty of Sports Science, Universitas Negeri Padang, Indonesia. His research fields include coaching volleyball sports. Email: hermanzoni@,fik.unp.ac.id

Sri Gusti Handayani, is a Lecturer in the Department of Sports Education, Faculty of Sports Science, Universitas Negeri Padang, Indonesia. His research areas include Sports Education. Email: srigusti@,fik.unp.ac.id

Muhamad Sazeli Rifki, is a Lecturer at the Department of Sports Science, Faculty of Sports Science, Universitas Negeri Padang, Indonesia. His research areas include Volleyball learning, and sports nutrition. Email: msr rifki@fik.unp.ac.id

Yanuar Kiram, is a Lecturer in the Sports Coaching Study Program, Faculty of Sports Science, Universitas Negeri Padang, Indonesia. His research areas include Motor Learning. Email: yanuarkiram@fik.unp.ac.id

Novadri Ayubi, is a Doctoral Student in Sports Science at the Universitas Negeri Surabaya, Indonesia. His research areas include sports health. Email: novadriayubii@, yahoo.com

Article submitted 2022-01-24. Resubmitted 2022-02-25. Final acceptance 2022-02-27. Final version published as submitted by the authors. 